\title{
MEMAHAMI HADITS TENTANG LA'NAT MALAIKAT TERHADAP ISTRI YANG MENOLAK AJAKAN SUAMI
}

\author{
Sobari Bin Sutarip \\ UIN Syarif Hidayatullah Jakarta \\ sobaris6@gmail.com
}

\begin{abstract}
The discussion about married life is an interesting discussion and becomes the focus of public attention. Islam commands to live in pairs and build a household. Islam pays serious attention to married life. Because human nature requires love and affection. Allah is in the form of male and female to live in pairs so that peace, love and compassion can be created. It is the duty of every saumi and wife to get along with their partner ma'ruf (well). However, A and building a household ark does not always run smoothly without the gravel and obstacles. This paper will discuss the life of a couple who experience disharmony in the household. Or specifically, this paper will examine the hadith about the cursing of angels against a wife who refuses her husband's invitation to have sex. In this hadith about la'nat, the steps taken by the researcher are as follows: First, compiling the hadiths that discuss related themes, especially from the poles. Second, mentakhrij and criticize the related hadiths. Third, the impression of the hadith syarh (muhaddithin) to understand the contents of the hadith. Fourth, the views of contemporary fuqoha 'and scholars on related themes. While the approach used is the fiqh approach as well as the social psychology approach and the medical approach.
\end{abstract}

Kata Kunci : Nusyuz, la'nat, Suami dan Istri

\section{A. Pendahuluan}

Diantara tanda kasih sayang Allah SWT, dijadikanlah manusia ini berpasang pasangan agar terjadi saling mengasihi satu sama lain, terjadi regenerasi demi keberlangsungan misi manusia yaitu sebagai kholifah di bumi, memakmurkan semesta dan tunduk taat beribadah kepada Allah SWT. Pernikahan merupakan kenikmatan yang sangat agung yang Allah anugerahkan kepada hambaNya. Pernikahan menduduki posisi yang tinggi dalam islam. Ia juga ikatan perjanjian yang sangat kuat antara dua insan kaum Adam dan Hawa. ${ }^{1}$ Sebagaimana firman Allah :

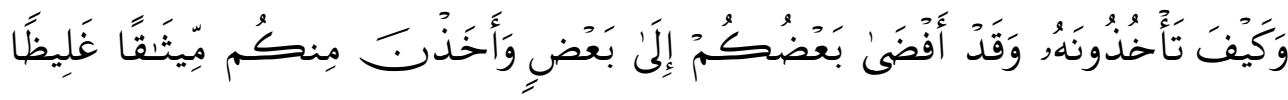

(النساء: (21)

Artinya: bagaimana kamu akan mengambilnya kembali, Padahal sebagian kamu telah bergaul (bercampur) dengan yang lain sebagai suami-isteri. dan mereka (isteriisterimu) telah mengambil dari kamu Perjanjian yang kuat.

\footnotetext{
${ }^{1}$ Imad al Hakim, Asror al Jima, Dar Al Ghod al Jadid, 5.
} 
Yang dimaksud dengan "mitsqon gholizo” menurut Ikrimah dan ar Rabi' adalah perjanjian dan mengambil kehalalan istri yang diikat dengan kalimat Allah. Mujahid dan Ibnu Zaid mengatakan bahwa "mitsqon gholizo" adalah akad nikah. ${ }^{2}$

Para pakar kedokteran dan kaum rasionalis telah sepakat bahwa obat dari penyakit hubb (cinta) adalah bertemunya dua ruh, bercampurnya dua jiwa dan bergabungnya dua badan. Imam Ahmad bin Hambal mengatakan : hidup membujang atau tidak mau kawin bukanlah termasuk ajaran islam, Rasulullah saw menikah sampai 14 istri dan ketika beliau meninggal dunia beliau meninggalkan 9 istri. Seandainya manusia meninggalkan pernikahan niscaya punahlah generasi manusia, matilah kehidupan, tidak ada peperangan, haji dan lain - lain. Rasulullah saw memilih menikah dan menganjurkan seseorang agar menikah. Siapa saja yang benci dengan sunnah Rasulullah saw sungguh berada di jalan yang tidak benar. ${ }^{3}$ Melakukan pernikahan, membangun bahtera rumah tangga merupakan perintah dan sunnah Rasulullah saw, namun dalam prakteknya, tidak selamanya kehidupan berumah tangga berjalan dengan mulus dan harmonis. Bumbu bumbu rumah tangga, kerikil - kerikil yang menghalangi lancarnya perjalanan rumah tangga pasti dialami semua pasangan suami istri. Dalam islam laki - laki merupakan kepala rumah tangga, suami bagi istri, bapak dari anak - anak dan mempunyai tanggung jawab besar terhadap jalannya bahtera rumah tangga. Disisi lain seorang istri adalah ibu dari anak - anak, guru di rumah serta teladan bagi anak - anak. Istri adalah mitra suami, masing - masing saling bahu - membahu dan saling melengkapi kekurangan satu dengan lainnya. Dalam istilah yang populer, az zauj syaqiqu az zaujah.

Dalam perjalanan berumah tangga kita mengenal istilah nusyuz, kata nusyuz merupakan istilah yang dipakai Al Quran. Sebagaimana yang tersebut dalam surat an Nisa, ayat 34 :

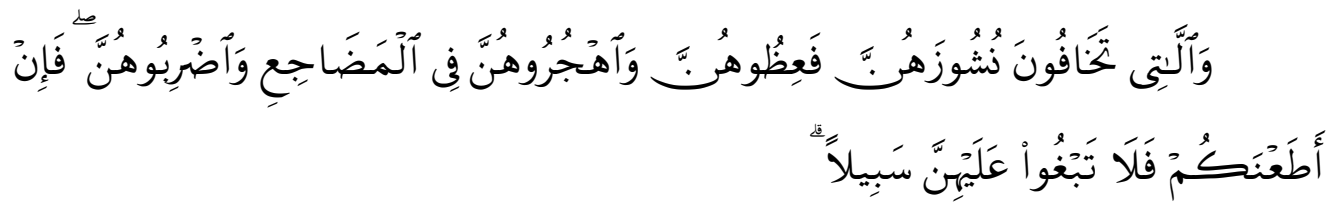

Artinya: Wanita-wanita yang kamu khawatirkan nusyuznya, Maka nasehatilah mereka dan pisahkanlah mereka di tempat tidur mereka, dan pukullah mereka (memukul yang tidak menyakiti fisiknya dan tidak diwajhnya). kemudian jika mereka mentaatimu,Maka janganlah kamu mencari-cari jalan untuk menyusahkannya. (an Nisa :34)

Nusyuz: Yaitu meninggalkan kewajiban bersuami istri. Nusyuz dari pihak istri seperti meninggalkan rumah tanpa izin suaminya. Sedangkan nusyuz dari pihak suami seperti sakit, tidak memberikan nafkah keluarga dan tidak menggauli istrinya dengan baik. ${ }^{4}$ Tahapan - tahapan yang ditempuh seorang istri ketika melihat indikasi bahwa seorang istri lagi nusyuz ada 3. Pertama, diberi nasehat dengan baik. Kedua, bila nasehat tidak bermanfaat barulah dipisahkan dari tempat tidurnya. Ketiga, bila pisah tempat tidur tidak bermanfaat juga barulah dibolehkan memukul tapi yang tidak menyakiti fisiknya dan tidak diwajah. Bila cara pertama telah ada manfaatnya janganlah dijalankan cara yang lain dan seterusnya.

\footnotetext{
${ }^{2}$ Abu Abdillah Muhammad bin Ahmad al Anshori al Qurthubi, tafsir al Jami' liahkam Al Quran, Dar Hadits, Cairo, jilid 5, 108 - 109.

${ }^{3}$ Imad Hakim, Asror al Jima'. 5.

${ }^{4}$ Abu Ishaq Ibrohim bin Ali bin Yusuf Al Fairuz Abazdi, Al Muhazdab, bab anNusyuz, jilid 2, 286.
} 


\section{B. Hadits Tentang Nusyuz}

1. Hadits riwayat imam Bukhori ${ }^{6}$

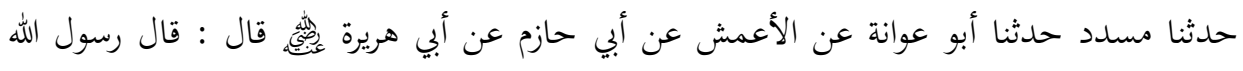

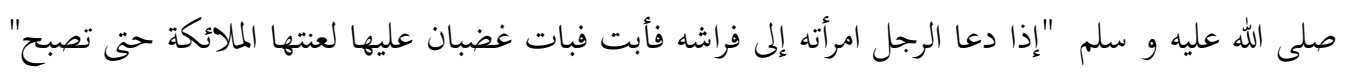

$$
\begin{aligned}
& \text { (رواه البخارى) }
\end{aligned}
$$

2. Hadits riwayat imam Bukhori, dengan jalur yang lain

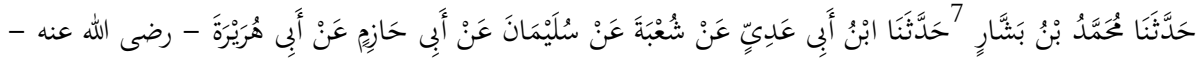

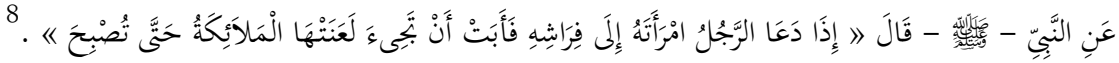

3. Hadits riwayat imam Muslim ${ }^{8}$

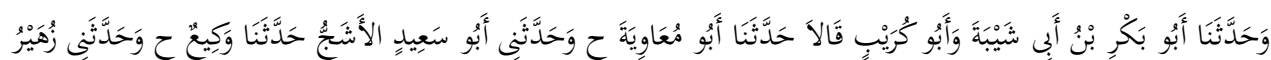

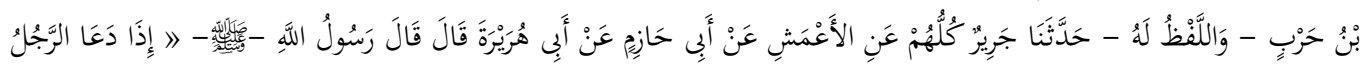

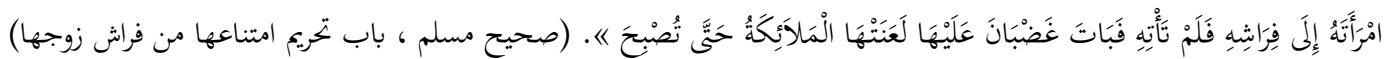

4. Hadits riwayat imam Muslim ${ }^{9}$

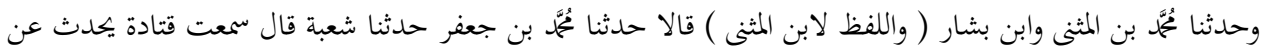

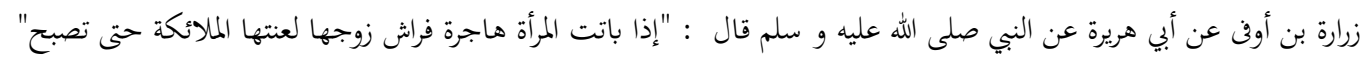

5. Hadits riwayat imam Muslim, sedikit berbeda redaksi matannya

$$
\begin{aligned}
& \text { وفي رواية قال رسول الله عليؤسلاله : "والذي نفسي بيده ما من رجل يدعو امرأته إلى فراشها فتأبى عليه، إلا كان الذي }
\end{aligned}
$$

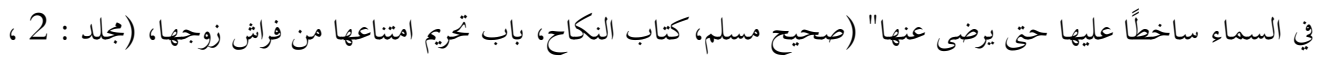

$$
\begin{aligned}
& \text { ص: 1060) }
\end{aligned}
$$

6. Hadits riwayat imam Abu Daud ${ }^{10}$

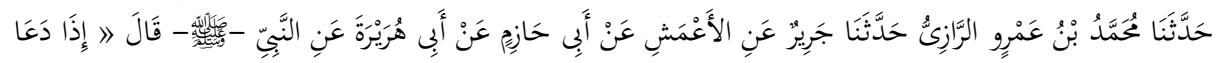

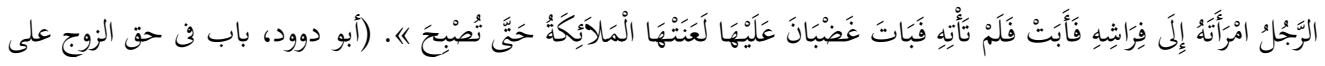

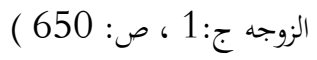

7. Hadits riwayat imam Ahmad bin Hanbal ${ }^{11}$

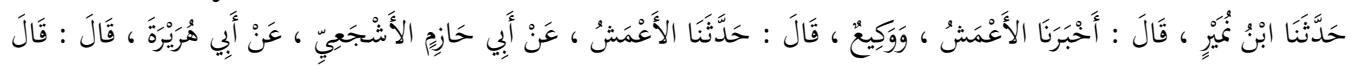

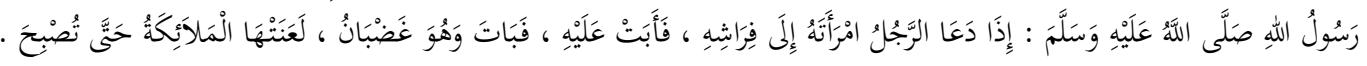

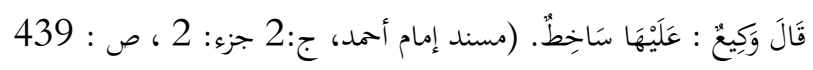

${ }^{5}$ Sebagian besar hadits di atas diakses dari maktabah digital (maktabah Syamilah)

${ }^{6}$ Muhammad Bin Ismail Abu 'Abdullah Al-Bukhari, Jami' As-Shohih, Juz 3, (Beirut: Dār Ibn Kașir, al-Yamāmah), 1182.

${ }^{7}$ Abu Basyar adalah Bundar, sedangkan Sulaiman adalah al A'masy,sedangkan Abu Hazim adalah Salman Al Asyja'i (lihat Fathul bari, bab : izda batat imroah muhajirota firosyi zaujihi)

${ }^{8}$ Muslim Bin Al-HajjājAbu Al-Hasan Al-QusyairiAn-Naisāburi, Shahih Muslim, Juz 5 ((Berut: Dār'IhyaAl-TurāṣiAl-'Arabi), 1060.

${ }^{9}$ Muslim, Shohih Muslim, juz 5, 1060.

${ }^{10}$ Sulaiman Bin Al-Asy’aș Abu Daud, Sunan Abi Daud,Juz1(DārAl- Fikr), 650.

11 Ahmad Bin Hambal Abu 'Abdullah As-Syaibāni, Musnad Ahmad Bin Hambal, Juz 2(AlQahirah: Muasasah Qurtubah), 439. 
8. Hadits riwayat imam Ibnu Hibban

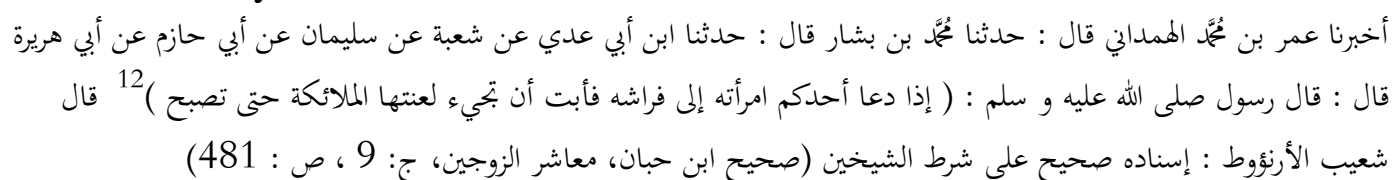

9. Hadits riwayat imam Al Baihaqi ${ }^{13}$

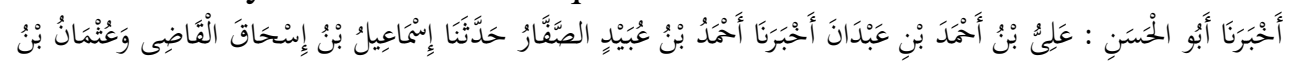

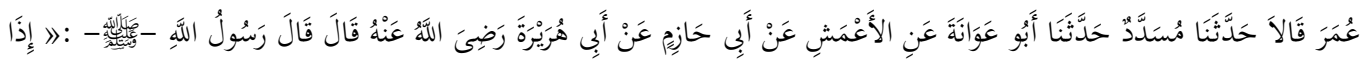

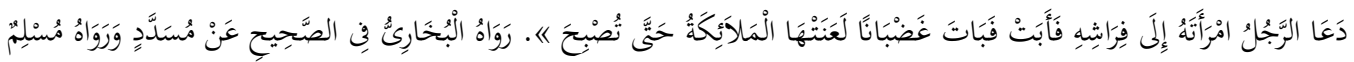

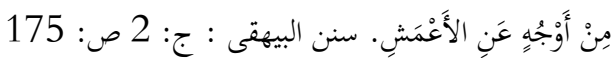

10. Dalam riwayat imam Bukhori, Muslim, Ahmad bin Hambal ada redaksi lain sebagimana yang dijelaskan imam Suyuthi dalam kitab Jam'ul Jawami' atau Al Jami' Al Kabir :

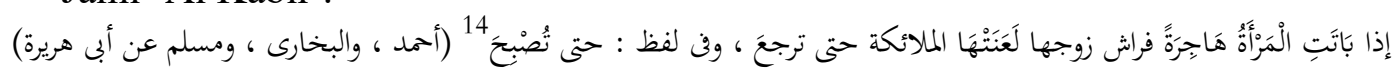

11. Dalam riwayat sunan Al Baihaqi radaksi sedikit berbeda menggunakan muhajiroh sedangkan di tempat lainnya menggunkan kalimat hajiroh.

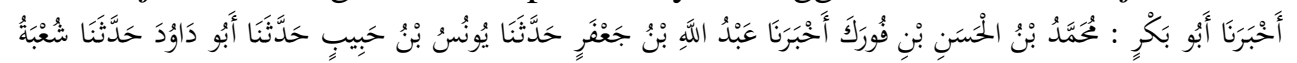

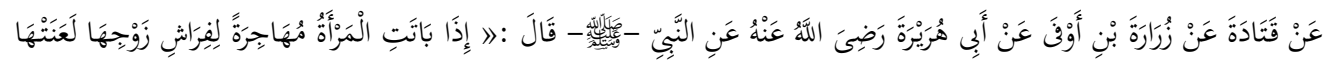

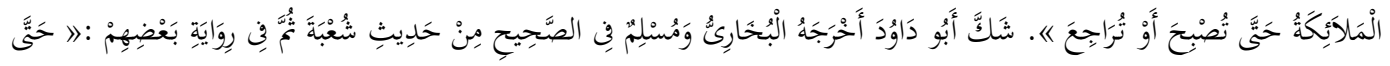

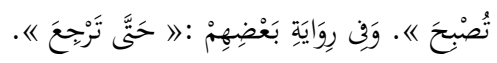

\section{Kritik Sanad}

Sanad merupakan hal yang paling spesifik sekaligus keutamaan khusus yang dimiliki umat ini, yang tidak dimiliki umat-umat lain sebelumnya. Dan termasuk sunah muakkad, seorang muslim bersandar kepada sanad dalam mentransfer hadits maupun berita. ${ }^{15}$ Berikut penyusunan skema sanad dari riwayat Abu Daud

1. Abu Hurairah ad-Dusi al-Yamani, sahabat Rasulullah SAW nama lengkap beliau terjadi perbedaan dikalangan para ulama ada yang mengatakan 'Abdurrahman bin Shakhr, ibn Ghanam, 'Abdullah bin 'Āid, ibn 'Amru, Sakin bin Ramzah Hani' dll.

$>$ Murid Ibn 'Abbas, Ibn 'Umar, Jabir, Marwan bin al-Hakim, Sa'id bin al-Musaibib, Abi Hazm dll.

$>$ Tahun Kematian57 $\mathrm{H}^{16}$

2. Abi Hazim

> Nama Lengkap Salamah bin Dinar Abu Hazim al-A'raj

${ }^{12}$ Shohih ibnu Hibban, jilid 9, bab Muasyir az Zaujain, hlm. 481, Syuaib al Ar Nauth mengatakan : isnad shohid, standar syarat Bukhori dan Muslim

${ }^{13}$ Abu Bakr Ahmad Bin Al-Husaini Bin 'Ali Al-Baihaqi, SunanAl-Baihaqi, Juz 2 (DāirahAlMa'ārifah), 175.

${ }^{14}$ Wisinki , dalam kitab Mu'jam li Al Fazhil hadits, An Nabawi an al kutub as sittab wa musnad ad Darimi wa muwatho' Ibnu malik wa Musnad Ahmad bin Hambal, bab "la'ana" mentakhrij hadist tersebuat : H.R Ahmad : jlid 2, hlm 386, Al Bukhori : jilid 5, hlm:1994, Muslim : jilid, hlm 1059, An Nasai fi al Kubro : jilid 5, hlm : 313, Ad Darimi: jilid 2, hlm: 201, Abu Awanah: jilid 3, hlm : 86, Ibnu Hibban: jilid : 9, 841 .

${ }^{15}$ Mahmud Thahan, IlmuHaditsPraktis, (PustakaThariqulIzzah, 2010), 235.

${ }^{16}$ Ahmad bin 'Ali bin HijrAbû al-Faḍl al-'Asqalāni al-Syāfi'I, Tahzib al-Tahzib, Juz 12(Beirut: Dār-Fikr, 1984), 288. 
Guru : Abi Umamah bin Sahal, Said bin al-Musayab, Ibnu Umar, Amir bin Abdullah, Abdullah bin Abi Qatadah dan lain-lain.

> Murid : al-Zuhri, Ubaidullah bin Umar, Ibnu Ishaq, al-Hamadani, Suaiman bin Bilal dan lain-lain.

Wafat 144

Komentar Ulama

Ahmad Abu Hatim dan 'Ajli dan an-Nasai ثقة IbnuKhuzaimah $={ }^{17}$

3. al-'Amasy

$>$ Nama Lengkap: Sulaiman bin Mihran

$>$ Guru :Anas, Zaid bin Wahab, Abu Hazim al-Asyza'i

$>$ Murid :Suhail bin Abi Shalih, Syubah, Ibnu Mubarak, Jarir bin Hazim

$>$ Tahun Kematian148 bulan Rabiul Awal

> Komentar Ulama

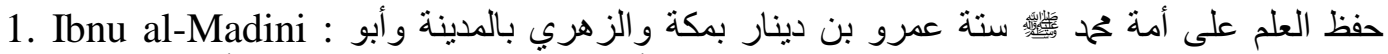

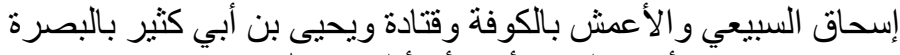

مأ رأيت بالكوفة أحدا أقر أ لكتاب الله منه:

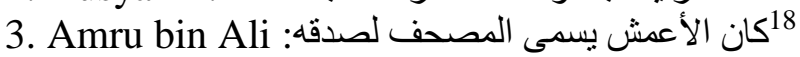

4. Jarir

$>$ Nama Lengkap Jarīr bin Hazim bin Abdullah bin Syujā'i

$>$ Guru Abu Tufail, al-Hasan, Qatadah, Ayub, Humaid bin Hilal, al-'Amasy

$>$ Murid Ibnu al-Mubarak, Yazid bin Abi Habib, Ibnu Aun, Abu Nuaim dan lainlain.

$>$ Tahun Kematian175

- Komentar Ulama

\begin{tabular}{|c|c|}
\hline al-Nasa'i & f f d t \\
\hline al-'Ijili & رى، تقة \\
\hline IbnuMuin & مقة . \\
\hline Abu Hatim & :" \\
\hline
\end{tabular}

5. Muhammad bin Amru al-Razi

$>$ Nama Lengkap Muhammad bin Amru bin Bakar bin Salim

$>$ Guru Hikam bin Salim, Harun bin al-Mugirah, Jarir bin Muslim, Salamah bin Fadl, dan lain- lain.

$>$ Murid :Muslim, Abu Daud, IbnuMajah, dan lain-lain.

$>$ TahunKematian241 H

$>$ Komentar Ulama

ثقة: يقة

IbnuHibban : ثقة:

IbnuSa'id : : :

\footnotetext{
${ }^{17}$ Ahmad bin 'Ali bin Hijr Abû al-Faḍl al-'Asqalāni al-Syāfí'I, Tahzib al-Tahzib, Juz 4(Beirut: Dār-Fikr, 1984), 124.

${ }^{18}$ Ahmad bin 'Ali bin Hijr Abû al-Fạ̣l al-'Asqalāni al-Syāfi'I, Tahzib al-Tahzib, Juz 4(Beirut: Dār-Fikr, 1984), 195.

${ }^{19}$ Ahmad bin 'Ali bin Hijr Abû al-Faḍl al-'Asqalāni al-Syāfi'I, Tahzib al-Tahzib, Juz 2(Beirut: Dār-Fikr, 1984), 61.

${ }^{20}$ Ahmad bin 'Ali bin Hijr Abû al-Fạ̣l al-'Asqalāni al-Syāfi'I, Tahzib al-Tahzib, Juz 9(Beirut: Dār-Fikr, 1984), 328.
} 
Secara umum Hadits - hadits diatas diriwayatkan oleh para perawi tsiqoot, dan termasuk dalam kategori hadits Shohih, sebagaimana pernyataan Al Arnauth dalam syarh sunan Abu Dawud mengomentari hadits tersebut : sanadnya Shohih mengikuti syarat Al Bukhori dan Muslim.

\section{Syarh Hadits}

Ibnu Hajar al Asqolani dalam Fathul bari menjelaskan :

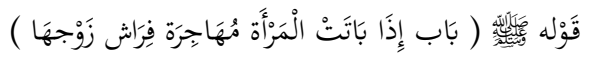

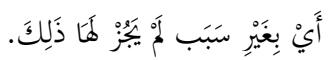

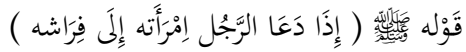

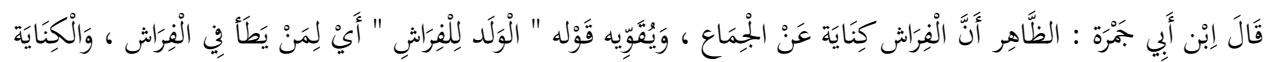

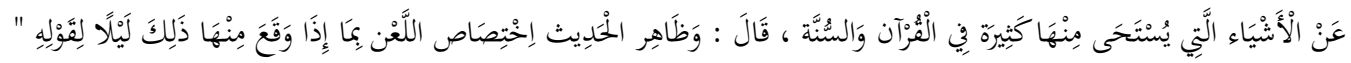

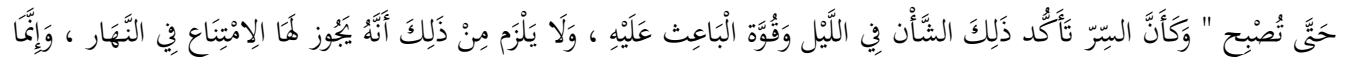

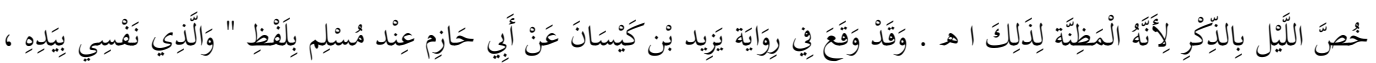

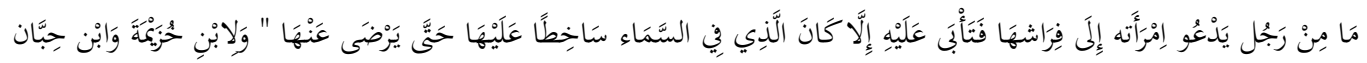

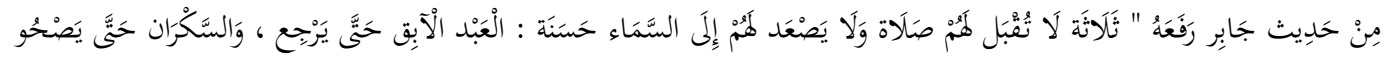

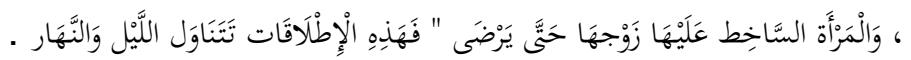

$$
\begin{aligned}
& \text { قَوْله }
\end{aligned}
$$

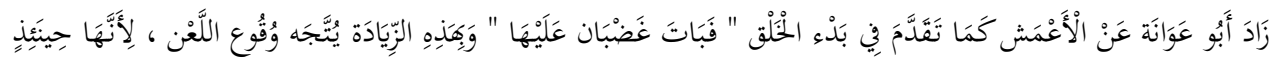

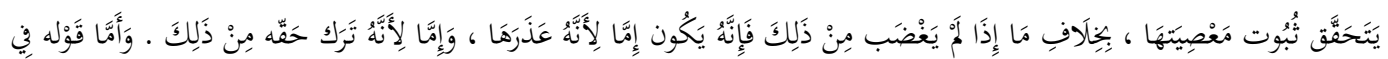

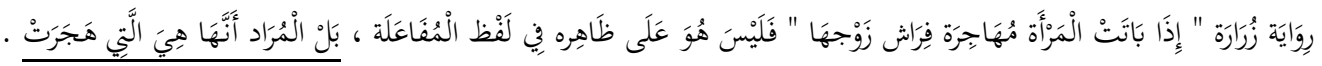

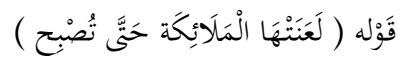

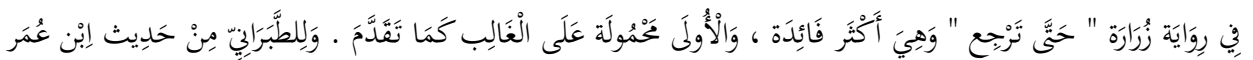

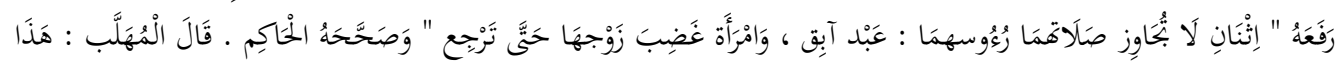

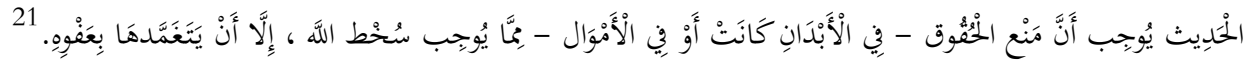

(Apabila seorang laki-laki memanggil istrinya ke tempat tidurnya). Menurut Ibnu Abu Jamrah, secara zhahir "tempat tidur" di sini merupakan kiasan perbuatan jima'. Hal ini didukung oleh sabdanya, الولد للفرش (anak untuk pemilik tempat tidur (suami yang sah), yakni untuk mereka yang melakukan hubungan intim di tempat tidur. Penggunaan kata kiasan sangat banyak dalam al-Qur'an dan Sunnah. Makna zhahir hadits tersebut adalah pengkhususan laknat kepada mereka yang melakukan hal itu semalaman berdasarkan perkataannya 'hingga subuh'. ${ }^{22}$

\footnotetext{
${ }^{21}$ Ibnu Hajar al Asqolani, Fathul bari, jilid : 4, 485 - 486.

${ }^{22}$ Ibnu Hajar al-Asqalani, Fathul Bāri, Syarah Sahih al-Bukhari Jilid 25, (Jakarta: Pustaka Imam Asy-Syafi'i, 2016), 659.
} 
فَبَاتَ غَضْبَا عَعَيْهَا (lalu ia melewati malam dalam keadaan marah terhadap istrinya). Dari sini diketahui alasan terjadinya laknat, karena pada saat seperti ini jelas bahwa dia telah melakukan kemaksiatan. Berbeda apabila suaminya tidak marah atas perbuatan itu, maka mungkin suaminya telah memaafkannya atau mungkin juga ia meninggalkan haknya. $^{23}$

لَعنَتْهَا الْمَلأَئكَةُ حَتَّى تُصْنحُ (Malaikat melaknatnya hingga subuh). Dalam riwayat Zurarah disebutkan, "hingga kembali". Versi pertama dipahami dalam konteks yang umum seperti dahulu. Ath-Thabarani mengutip dari hadits Ibnu umar dan dinisbatkan kepada Nabi saw

(Dua golongan yang shalat keduanya tidak melewati kepala mereka; hamba yang melarikan diri, wanita yang suaminya marah hingga ia kembali). Hadits ini dinyatakan shahih oleh al-Hakim. ${ }^{24}$

Pendapat yang lebih benar, maksud mereka yang melarang melaknat adalah maknanya secara bahasa, yakni menjauhkan dari rahmat Allah, dan ini tidak patut didoakan untuk seorang muslim, bahkan seharusnya dimintakan hidayah, taubat, dan kembali dari perbuatan maksiat. Adapun yang diperbolehkannya adalah mencelanya. Hal ini berdasarkan makna urf. Hadits di bab ini menyinggung malaikat yang melakukan laknat. Namun yang demikian tidak berkonsekuensi perbuatan tersebut diperbolehkan secara mutlak. ${ }^{25}$

$>$ Imam Nawawi dalam syarh Shohih Muslim menjelaskan :

$$
\begin{aligned}
& \text { قوله }
\end{aligned}
$$

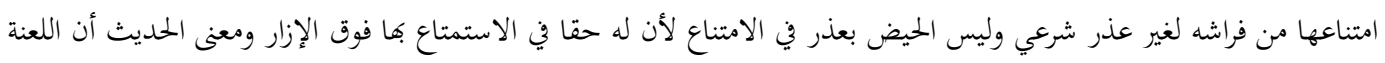

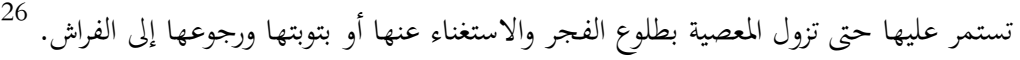

Al Munawi dalam Faidhul qodir menjelaskan hadits :

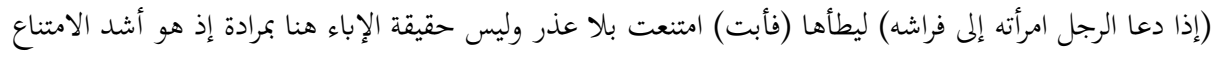

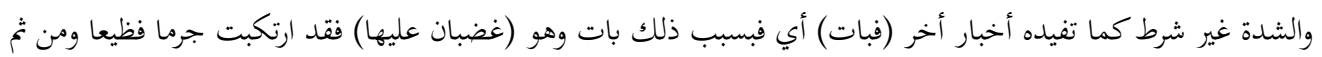

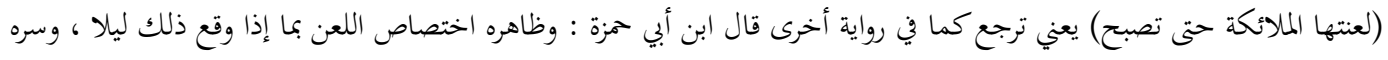

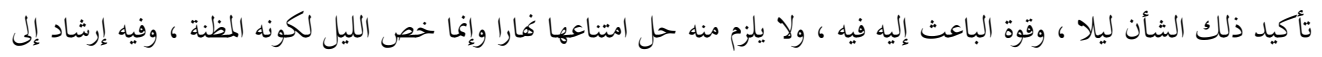

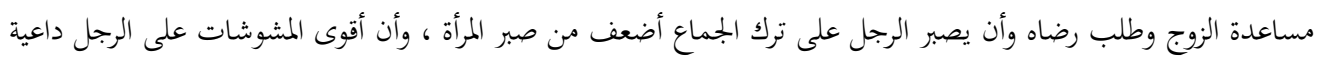

$$
\begin{aligned}
& \text { النكاح ، ولذلك حث المرأة على مساعدته على كسر شهوته ليفرغ فكره للعبادة أه. }
\end{aligned}
$$

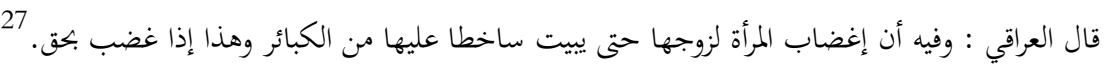

\section{E. Pandangan Para Fuqoha'}

Diantara hak - hak suami terhadap istri adalah taat kepada suami dan tidak keluar rumah tanpa izin suami. Sedangkan diantara hak - hak istri adalah memberikan mahar kepada istri, memberi bagian yang adil diantara para istri, memberi nafkah dan lainnya.

\footnotetext{
${ }^{23}$ Ibnu Hajar al-Asqalani, Fathul Bāri, Syarah Śahih al-Bukhari Jilid 25, (Jakarta: Pustaka Imam Asy-Syafi'I, 2016), 660.

${ }^{24}$ Al Hakim, al Mustadrok ala Ash Shohihaini, jilid 17, 176.

${ }^{25}$ Ibnu Hajar al-Asqalani, Fathul Bāri, Syarah Sahih al-Bukhari Jilid 25, (Jakarta: Pustaka Imam Asy-Syafi'I, 2016), 661.

${ }^{26}$ An Nawawi, Syarh Shohih Muslim, Dar al Fajr li at Turats, Cairo, jilid : 5, 233.

${ }^{27}$ Al Munawi, Faidhulqodir (syarh al jami’ Ash Shoghir, jilid : 1, 442.
} 
Adapun bergaul dengan ma'ruf merupakan kewajiaban kedua pasangan baik suami maupun istri. ${ }^{28}$

Nusyuz bisa muncul dari salah satu pasangan, adakalanya dari suami atau dari istri. Ketika tanda - tanda nusyuz nampak pada seorang istri (seperti ucapan yang kasar menyakitkan, padahal kebiasaan sebelumnya kalau berbicara halus dan sopan). Al Bujairimi menjelaskan makna nusyuz yaitu :

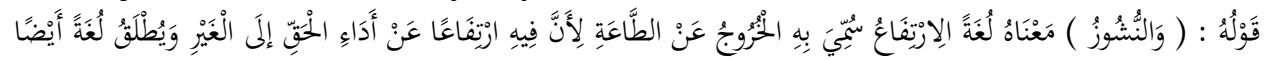

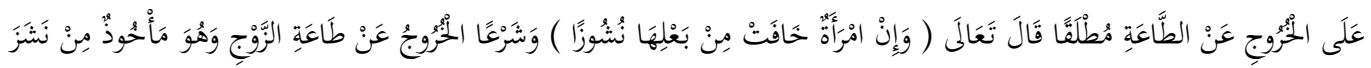

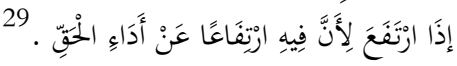

Sulaiman bin Jamal dalam kitab hasyiyah al Jamal al al Minhaj menjelaskan bahwa nusyuz adalah :

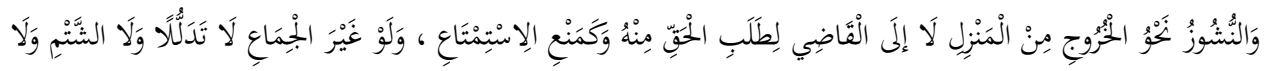

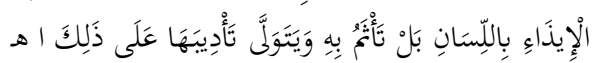

Termasuk dalam kategori nusyuz adalah bermuka masam, hal ini karena bermuka masam berdampak pada kenikmatan dalam berhubungan intim suami istri, berbeda kalau hanya sebatas ucapan yang mengandung cacian dan makian.

An Nawawi dalam kitab al Majmu' menjelaskan bahwa:

wajib hukumnya bagi istri untuk taat kepada suami, ketika suami mengajak untuk melakukan hubungan intim walaupun diatas atau tungku atau diatas unta, sebagaimana Rasulullah saw bersabda :

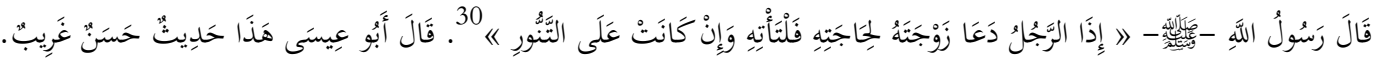

$$
\begin{aligned}
& \text { قال الشيخ الألباني : صحيح }
\end{aligned}
$$

selama tidak menyibukkan dan melalaikan kewajiaban atau selama tidak memberikan madhorot kepda istri. Karena kemadhoratan dan semisalnya tidak termasuk muasyaroh bilma'ruf. ${ }^{31}$

Kholid bin Usman as Sabt ( ulama kontemporer) memberikan penjelasan terkait hadits di atas :

$$
\begin{aligned}
& \text { فقول النبي علبوكسلمه : إذا دعا الرجل امرأته إلى فراشه يعني: المقصود إلى الجماع والمعاشرة، ولكن الشارع يكنيّي، فئكنَّى } \\
& \text { بالفراش عن الوقاع. }
\end{aligned}
$$

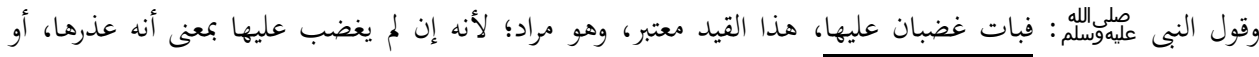

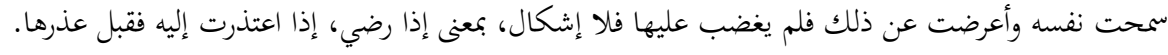

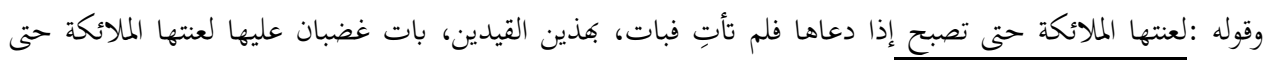

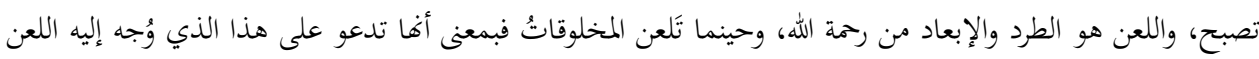

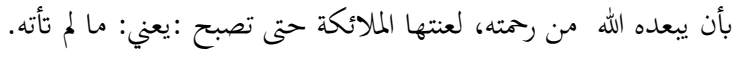

${ }^{28}$ Sulaiman bin jamal, hasyiayatul jamal ala Al minhaj, jilid 17, 410.

${ }^{29}$ Al Bujairimi, hasyiyatul bujairimi ala al Khothib, dalam kitab an Nikah, fashlun fi al qosam wa anNusyuz, jilid 10, 366.

${ }^{30}$ Muhammad bin Isa At Tirmidzi, Sunan at Tirmidzi, dar ihya 'at turats, Bairut, juz 3. Bab : Haqq az Zauj 'ala az zajah, 465.

${ }^{31}$ Muhyiddin An Nawawi, Al Majmu', jilid 7, 335. 


$$
\begin{aligned}
& \text { وقوله إذا باتت المرأة والمبيت إنما يكون بالليل، فهل هذا مفهومه معتبر؟، بمعنى أنه لو دعاها بالنهار فلم تأته هل يتحقق }
\end{aligned}
$$

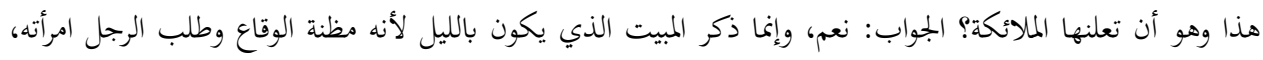

$$
\begin{aligned}
& \text { بخلاف النهار، فإن ذلك لا يحصل في غالب أحوال الناس، فهذا يستوي فيه الليل والنهار. } \\
& \text { وقوله إذا باتت المرأة هاجرة فراش زوجها لعنتها الملائكة حتى تصبح، ما قال: فبات غضبان عليها، هاجرة فراش زوجها }
\end{aligned}
$$

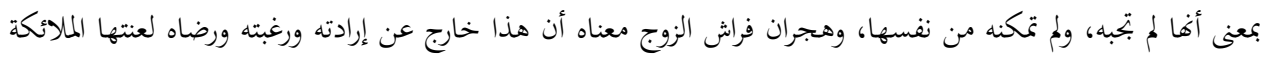

$$
\begin{aligned}
& \text { حتى تصبح. } \\
& \text { فتأبى عليه إلا كان الذي في السماء ساخطاً عليها حتى يرضى عنها ما قال: حتى يصبح، هناك قال :حتى يرضى عنها }
\end{aligned}
$$

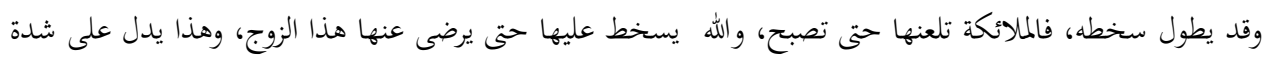

$$
\begin{aligned}
& \text { وعظم حق الزوج على المرأة، وفي الوقت نفسه أيضاً المرأة لا تُظلم. } 32
\end{aligned}
$$

Apakah penolakan seorang istri terhadap suaminya merupakan suatu bentuk pembangkangan dan ketidaktaatan seorang istri secara mutlak? akan berakibat terlaknatnya seorang istri secara mutlak? Dalam hal ini Kholid bin Usman memberikan pandangan bahwa jika istri dalam kondisi sakit atau kondisi psikologi lagi bersedih misal karena kerabat dan keluarganya baru saja meninggal maka ini tidak termasuk pembangkangan dan tidak ketaatan seorang istri.

أن للمرأة أن تمتنع في حالات، فالشريعة ما جاءت بالضرر، مثلاً: إذا كانت مريضة، أو كانت في حال من الحزن والهم، يعني: تعاني معاناة نفسية وقلبية، مات لها قريب مثلا فهي حزينة لأجله، فلمرأة لديها مشاعر، قد يكون هذا الإنسان في حال معها يعني :يظلمها ويؤذيها ويضربها وما أشبه ذلك، فتعذرت يعني رغبتها وتعذرت إجابتها لهذا الرجل، فما استطاعت أن بتجيبه

Pandangan Medis Terkait Hubungan Intim Suami Istri

Diantara cara mencegah kanker prostat pada pria adalah berhubungan intim dengan istri secara teratur, standar umumnya 2 atau 3 kali dalam sepekan. Penelitian membuktikan bahwasanya seringnya berhubungan intim dengan pasangan mencegah resiko terkena kanker prostat.

Bila mereka para pasangan suami istri berhubungan seksual secara teratur, mereka terhindar dari kanker yang menduduki peringkat ke-3 yang mematikan. Peneliti percaya bahwa pria yang paling aktif secara seksual, kecil kemungkinan untuk tertular penyakit yang berpotensi fatal. Berhubung pada kebanyakan kasus tidak ada gejala yang terlihat, kanker prostat pun begitu ditakuti dan berusaha untuk dihindari oleh kebanyakan pria. Sebelum mengeluarkan pendapatnya ini, para peneliti dari Boston terlebih dahulu melakukan satu studi yang melibatkan hampir 30.000 pria berusia 46 dan 81 tahun. Ketika itu, para pria ditanya mengenai ejakulasi yang mereka rasakan ketika berusia 20, 40, dan sebelum tahun 1991. Dari hasil yang telah diterbitkan di Journal of American Medical Association pada 2012, sebanyak 1.449 orang mengalami kanker prostat delapan tahun kemudian, terlebih bagi mereka yang hanya memiliki 4 sampai 7 ejakulasi per bulan. Melansir Daily Mail, Rabu (4/2/2015), peneliti juga melaporkan tidak ada peningkatan risiko kanker prostat pada pria yang mengaku sering kali melakukan itu. Apalagi bila mereka memiliki 13 sampai 20 kali ejakulasi perbulan akan mampu mengurangi resiko mengidap kanker prostat hingga 14 sampai 33 persen. Pemimpin penelitian yang berasal dari Cancer Institute, Dr. Michael Leitzmann, berpikir bahwa kegiatan semacam itu berefek memberikan perlindungan karena prostat

\footnotetext{
${ }^{32}$ https://khaledalsabt.com/explanations diakses 14 Maret 2018
} 
mengeluarkan sebagian besar cairan dalam air mani. Dan berhubungan seksual dapat membuang bahan kimia penyebab kanker. ${ }^{33}$

\section{F. KESIMPULAN}

Diantara hak suami terhadap istri adalah mentaatinya, tidak keluar dari rumah tanpa izin suami. Hak istri terhadap suami adalah memberikan mahar, memberikan nafkah, berlaku adil dan seterusnya. Adapun bergaul dengan ma'ruf adalah kewajiban masing - masing dari suami maupun istri. ${ }^{34}$ Seorang istri boleh menolak ajakan suami karena beberapa alasan ; Pertama, istri sedang sakit dan dinyatakan secara medis akan membahayakan kondisinya jika berhubungan intim dengan suami. Kedua, ketika kondisi psikologi tidak stabil atau lagi tergoncang, misal salah satu keluarga istri baru saja meninggal. Ketiga, suami termasuk orang yang fajir, suka mabuk - mabukan, misalnya, maka istri boleh menolak ajakan suami, atau suami suka bermain perempuan (yang tidak halal), maka istri boleh menolak ajakan suami dengan alasan kawatir tertular penyakit aids misalnya. Hal ini karena agama islam memulyakan dan menghormati manusia, tidak boleh menyia - nyiakan manusia.

Selain beberapa alasan diatas dan tidak ada uzdur, maka wajib bagi istri melayani suaminya dan mentaatinya. Ancaman malaikat melaknat istri yang tidak taat, sebagaimana yang dijelaskan di atas, tentu ada hikmah lain yang sebagian tersingkap oleh keilmuan baik secara psikologi atau medis. Terakhir, membudayakan komunikasi yang baik, keterbukaan antara masing - masing pasangan suami istri dan saling memahami adalah kunci kesuksesan bahtera rumah tangga.

\section{DAFTAR PUSTAKA}

Abu Bakr Ahmad Bin Al-Husaini Bin 'Ali Al-Baihaqi, SunanAl-Baihaqi (Dāirah AlMa'ārifah)

Abu Ishaq Ibrohim bin Ali bin Yusuf Al Fairuz Abazdi, Al Muhazdab

Ahmad Bin Hambal Abu 'Abdullah As-Syaibāni, Musnad Ahmad Bin Hambal (AlQahirah: Muasasah Qurtubah)

Ahmad bin 'Ali bin Hajr Abû al-Faḍl al-'Asqalāni al-Syāfi'I, Tahzib al-Tahzib (Beirut: Dār-Fikr, 1984)

Al Bujairimi, hasyiyatul bujairimi ala al Khothib

Al Hakim, al Mustadrok ala Ash Shohihaini

Al Munawi, Faidhulqodir (syarh al jami’ Ash Shoghir)

Ibnu Hajar al-Asqalani, Fathul Bāri, Syarah Ṡahih al-Bukhari, (Jakarta: Pustaka Imam Asy-Syafi'I, 2016)

Imad Hakim, Asror al Jima'

Abu Abdillah Muhammad bin Ahmad Al Qurthubi, Tafsir Al Qurthubi

Mahmud Thahan, IlmuHaditsPraktis, (PustakaThariqulIzzah, 2010)

Muslim Bin Al-Hajjāj Abu Al-Hasan Al-QusyairiAn-Naisāburi, Shahih Muslim, ((Berut: Dār'I hyaAl-TurāṣiAl-'Arabi)

Muhammad bin Isa At Tirmidzi, Sunan at Tirmidzi, Bairut Dar ihya 'at turats

Muhammad Bin Ismail Abu 'Abdullah Al-Bukhari, Jami' As-Shohih,

33 https://www.liputan6.com/health/read/2170670/rutin-hubungan-intim-kanker-prostat-pergi,

diakses 8 Maret 2018

${ }^{34}$ Hasyiah al Bujairimi ala al Khotib, $165-166$. 
( Beirut: Dār Ibn Kașir, al-Yamāmah)Al Jami’ li Ahkam Al Quran

Muhyiddin An Nawawi, Syarh Shohih Muslim, Dar al fajr li at Turats, Cairo

Sulaiman bin jamal, hasyiayatul jamal ala Al minhaj

Sulaiman Bin Al-Asy'aṣ Abu Daud, Sunan Abi Daud,(Dār Al- Fikr)

Muhyiddin An Nawawi, Al Majmu'

https://khaledalsabt.com/explanations/diakses pada tanggal 8 Nov 2019

https://www.liputan6.com/health/read/2170670/rutin-hubungan-intim-kanker-prostatpergi\# diakses 8 November 2019

Wisinki, dalam kitab Mu'jam li Al Fazhil hadits, An Nabawi an al kutub as sittab wa musnad ad Darimi wa muwatho’ Ibnu malik wa Musnad Ahmad bin Hambal. 